\title{
МАТЕРИНСТВО ЯК ЛІНГВОКУЛЬТУРНЕ ЯВИЩЕ
}

Демиденко Г. Г. Материнство як лінгвокультурне явище.

У статті розглянуто явище материнства 3 позиції його лінгвальної інтерпретації; визначено групи фразеологічних одиниць, що виражають усталені в лінгвокультурі стереотипні погляди на вагітність жінки, народження нею дітей, їх вигодовування, виховання та ін. Звернено увагу на особливості лексичної номінації дій, процесів, станів, пов'язаних 3 материнством, з'ясовано його соціокультурну характеристику в межах українського комунікативного простору.

Ключові слова: фразеологізм, материнство, мати, дитина, вагітність, виховання, евфемізм, код культури.

С Г. Г. Демиденко, 2016. 


\section{СТРУКТУРА І СЕМАНТИКА МОВНИХ ОДИНИЦЬ}

Демиденко А. Г. Материнство как лингвокультурное явление.

В статье рассматривается явление материнства с точки зрения лингвистической интерпретации; определены группы фразеологических единиц, выражающих сложившиеся стереотипные взгляды на беременность женщины, рождения ее детей, их вскармливание, воспитание и др. Внимание обращается на особенности лексической номинации действий, процессов, состояний, связанных с материнством, дана его социокультурная характеристика в рамках украинского коммуникативного пространства.

Ключевые слова: фразеологизм, материнство, мать, ребенок, беременность, воспитание, эвфемизм, код культуры.

Demydenko H. H. Motherhood as a linguistic and cultural phenomenon.

The article investigates the motherhood phenomenon in terms of linguistics. This paper focuses on the clarifying its sociocultural characteristics within Ukrainian communicative space. While this research it has been determined that the motherhood signs verbalized by idiomatic expressions and related to the mother archetype are associated with such notions as care, compassion, kindness, care, support etc. Mother image within the Ukrainian tradition gets a significant emotional and expressive semantics in its modifications as mother, mum, mammy.

This research defines the set of idioms that express established Ukrainian stereotypical views about pregnant women, giving birth to a child, children's feeding, bringing them up etc. in Ukrainian culture. The main attention is drawn to the statements containing the central lexical component "mother", outlining their diverse semantic potential. This paper determines that the social and biological experience of being a mother recorded mostly in set idioms expressions and idioms relevant within individual dialects. Such idioms have euphemistic nature and are identified by comparing the relevant events in the lives of women and society with nominations, which in the context of the Ukrainian cultural tradition are manifested as a form of the communicative compromise. Mentioned idioms demonstrate the desire to avoid direct nominations of pregnancy process and pregnancy itself, inability to become pregnant, unwanted pregnancy and childbirth etc. The reason causing such transformations is connected with the desire to avoid communicative conflict or distract attention from a woman in order not to curse or hurt her. Thus, the nomination of a pregnant woman due to special attitude, public opinion influence (condemnation, contempt, approval, admiration) gets different modifications.

This article represents various illustrations of above mentioned euphemistic idiomatic expressions supplying them with linguistic and cultural commentary in correspondance to cultural codes of the actual language material.

Key words: idiom, motherhood, mother, child, pregnancy, bringing up, euphemism, cultural code.

У сучасних лінгвістичних розвідках посилюється тенденція до вивчення загальнокультурних універсалій через мовні одиниці 3 урахуванням структури людського знання, ментальних процесів, що стали підгрунтям для мовної номінації. Материнство як 
соціокультурний феномен містить у собі генезис усієї людської культури та цивілізації, усього суспільно-історичного та родинного досвіду людства $[6$, с. 10]. Образ матері є константною величиною й української етнокультури і має свої специфічні проекції на лексикофразеологічну систему. Зрозуміло, що материнство не має національності, адже здебільшого констатує біологічну складову життя людини, однак у кожній етноспільноті це явище набуває індивідуальних ознак, самобутніх рис. Унікальність, важливість, невичерпний потенціал феномена матері в межах будь-якого суспільства підтверджують дослідження зарубіжних і вітчизняних учених різних царин наукового пізнання. Здебільшого вивчалися концепти МАТИ і МАТЕРИНСТВО в лінгвістиці (Н. Аванесян, М. Адреянова, А. Алієва, В. Калько, Ж. Колоїз, А. Рахмат, А. Рижкіна, О. Смирнова, А. Чернова), у літературі (С. Бартіш, М. Марусяк, Ж. Марфіна), педагогіці (3. Нагачевська, М. Сіренко) та лінгводидактиці (М. Кононенко).

Перше слово, вимовлене дитиною, - це мама, воно орієнтує на історичну добу, коли головою роду і родини була матір, а не батько (епоха матріархату). Цю обставину фіксує генетичний код людини, що реалізується передусім у мові, адже в екстрених ситуаціях вона до кінця життя звертається до мами [3, с. 356]. За вдалим висловом Е. Фрома, «мати - це харчування, любов, тепло, земля. Перебувати в іiі любові - означає бути живим, мати коріння та відчуття дому» $[11$, c. 305]. Материнство є повноцінним компонентом українського соціокультурного простору, 3 матері бере початок нове життя, на образі матері грунтуються уявлення про безліч інших понять у житті та світогляді народу, зокрема про державу, рідну землю тощо. У зв'язку 3 цим на сьогодні залишається актуальним питання вербалізації явища материнства з позиції лінгвокультурології.

Мета наукової розвідки полягає у тому, аби 3'ясувати лінгвістичну сутність материнства, материнської поведінки, ставлення до матері в українському соціумі. Задля досягнення поставленої мети маємо виконати такі завдання: 1) виявити й систематизувати корпус українських фразеологічних одиниць (далі - ФО), що актуалізують соціокультурну й біологічну підоснову материнства; 2) визначити лексичні номінації досліджуваного явища, поширені в комунікативному етнопросторі.

○ Г. Г. Демиденко, 2016. 
Насамперед зауважимо, що за визначенням О. Левченко, фразеологічна репрезентація світу відрізняється від лексичної більшою архаїчністю, міфологізованістю, а ФО мають більший обсяг та інший характер інформації, ніж одиниці лексичного рівня [4, с. 314]. В усталених зворотах збережено різні знання, актуалізовані суб'єктом під час їх безпосереднього використання у процесі мовлення. За таких умов дослідження фразем на рівні асоціативного сприйняття та оцінювання дійсності узагальнюють погляди носіїв мови. Усталені вислови в мовній свідомості репрезентують вербалізований продукт вторинного відображення картини світу. На думку О. Селіванової, «фразеологічна номінація отримала новий дослідницький вектор - аналіз і моделювання психоментального підгрунтя вибору тієї чи тієї зовнішньої форми з огляду на культуру народу, структуру етносвідомості та їхню еволюцію» [9, с. 16].

За огляду на сказане вище варто розглядати передусім фразеологізми української мови, внутрішня форма яких ілюструє уявлення i знання про материнство. Насамперед зазначимо, що материнство розуміють як «1) біологічну функцію жіночого організму, спрямовану на продовження людського роду; стан жінки під час вагітності, пологів, годування дитини; 2) соціальну функцію матері, що полягає у вихованні дитини; почуття жінки-матері до дитини; бажання стати матір'ю» [1, с. 651]. Очевидно, що ключовою для розуміння власне материнства є лексема мати, яка має таку парадигматику: матір (урочисте), мама (розмовне), неня, ненька (розмовне), матірка (фамільярне), родителька (застаріле) (2, с. 101). 3-поміж інших номінацій фіксуємо такі: матер (3, с. 123), мамдзя (зневажливе) (3, с. 122), мамуха (3, с. 122); мамка, мамойка, мамунийка, мамуниуня, мамуния, мамия (8, с. 428-429).

Як стверджує А. Рижкіна, слово mother (мама) в англійській й mater (мама) у латинській мові $є$ схожими, адже мають загальновідомий етимон $m a$ «груди» + індоєвропейський суфікс ter, тому етимологічний зміст слова mother - «грудне вигодовування» [7, c. 97].

Материнство передбачає комплексний вияв поведінкових реалій, дій, процесів, пов'язаних із жінкою, дитиною, родиною, а відтак його характеризують звороти різнотипні за конструкцією. Так, очевидно, передусім варто звернути увагу на ФО з компонентом мама 
(мати, матір) та похідних від нього, а саме: як (у чому, у чім) мати [на світ] народила (породила) (9, с. 371) - «зовсім голий, без одягу»; [ще] [материне] молоко на губах не обсохло (9, с. 403); мати материнське молоко на бороді $(11$, с. 85); мати материнське молоко на языку (попуд нюсом) (11, с. 86) - «хтось дуже молодий, неповнолітній, недосвідчений», з молоком матері (9, с. 403) - «від народження, $з$ перших днів життя»; од материнуй ціичкы - «з дитячих літ відбувається що-небудь» $(11$, с. 141); смоктати мамину цฺиц̧ю «бути дуже малим» (9, с. 671); добрый як мамина ціцика - «дуже добрий» (11, с. 142); мамин синок - «розпещений хлопчик або юнак» $(9$, c. 647), мамин мізинчик - «наймолодша в сім’ї дитина // малий на зріст» (9, с. 391). Як бачимо, семантичний обшир наведених прикладів ілюструє взаємозв'язок матері 3 дитиною, появу на світ несамостійної істоти, що потребує захисту, елементарної уваги до себе і піклування. Прикметно, що образність наведених фразем має біологічно виправдане підгрунтя, адже діти дійсно народжуються голими, їх вигодовують материнських молоком 3 перших годин життя (за умови вдалих пологів, гарного самопочуття новонародженого й породіллі). Малюк не може проявити самостійність під час годування, він невмілий, молоко здебільшого розтікається, може залишатися на губах.

Фраземи молоко на губах не обсохло (9, с. 403), з молоком матері (9, с. 403) та подібні фіксують реалізацію так званого предметно-глютонімного культурного коду (за Л. Савченко), де терміном глютонім позначаються «назви сировини, напівфабрикатів, страв, харчових продуктів та консервів, напоїв, номінації їжі без зазначення складу» [8, с. 122]. Центральним символом у цьому коді виступає компонент на позначення продукту споживання - молока. В українській культурно-харчовій традиції молоко вважають «символом примноження» [3, с. 375], це напій для годування дітей, який має весь необхідний запас мікроелементів для повноцінного розвитку людини в перший рік життя. У коров'ячому молоці здавна купали дітей, аби «тіло повне і біле було» [3, с. 375], за народними повір'ями, не можна на ніч залишати молоко відкритим - його п'є нечиста сила, коли молоко давали в чужу хату, насипали туди солі, аби відьма не попсувала корови [3, с. 375].

У структурі стійких зворотів смоктати мамину цุицюю $(9$, с. 671),

() Г. Г. Демиденко, 2016. 
материну ціцчку ссав - «був у дитячому віці» (11, с. 141) наявний соматизм циицяя - «сосок людини або самки тварини; жіночі груди» [1, с. 1586] 3 емоційно-експресивним відтінком розмовності. Ця лексема вживається переважно в побутових комунікативних ситуаціях, які стосуються дітей, узаємодії матері й дитини. Передусім вислови акцентують на вікових особливостях, і подекуди, на нашу думку, має іронічний чи глузливий підтекст. До уваги не береться сакрально-міфологічна роль жіночих грудей, які стають для дитини джерелом насолоди та задоволення.

3-поміж досліджуваних лінгвоодиниць зацікавлення викликають звороти, пов'язані 3 релігійною сферою життя. Образ матері як берегині роду перетинається з образом Матері Божої, про що свідчить план вираження українських фразем, у яких Богоматір позиціонується як оберегова сила. Наприклад: Мати Божа - «уживається для вираження позитивних або негативних емоцій: радості, здивування, захоплення, переляку» (9, с. 370); хай (нехай) мати Божа милує (прощає, боронить, помилує) - «уживається для вираження побажання кому-небудь добра, безпеки, благополуччя; щоб було все добре» (9, с. 370). Друга наведена ілюстрація позиціонує Матір Божу як помічницю, захисницу, і реалізуються у вербальному коді замовлянь $[12$, c. 483$]$.

Як демонструє фактичний матеріал, подекуди ФО 3 компонентом мати характеризують негативні якості людини, iii поведінки: щзо за вража (лиха) мати - «уживається для вираження здивування, досади, незадоволення» $(9$, с. 370); вража (лиха, хрінова) мати (9, с. 370]; трясия його (ї̈, їхній, твоїй, вашій) матері (9, с. 725); пся мати - «бездушна, безсердечна людина» (11, с. 82). У фамільярному контексті уживаються вислови: враг його (ix) [матір (душу)] знає - «невідомо» (12, с. 150); враг його матері $(11$, с. 150) «уживається для вираження задоволення або незадоволення». Негативна експресія цих фразем значно інтенсифікується завдяки відповідним лексемам лихий, вражий (ворог), хріновий, псячий, де пес є уособленням злості, жорстокості, недоброзичливості [3, с. 557].

Важливим етапом у житті жінки-матері $є$ вагітність - «1) стан жінки в період розвитку в її організмі плоду; 2) процес розвитку плоду 3 заплідненої яйцевої клітини в материнському організмі людини і живородних тварин» [1, с. 107]. У народній традиції цей стан 
оцінюється двояко: народження дитини визнається головною метою шлюбу, а вагітна жінка уособлює родючість, їй приписують оберегові, цілющі й інші благодійні властивості, хоч побутує думка й про небезпеку, нечистоту, адже у вагітній жінці наявні дві душі, близькі до межі життя і смерті [3, с. 62].

В українському комунікативному просторі функціонують такі номінації вагітної жінки: груба (7, с. 26; 4, с. 95-96; 1, с. 50; 13, с. 97), веремінна огрєдна, самодруга, тєшка (кішка́) (1, с. 50); черевата (зневажливо) (1, с. 211); важна (3, с. 39); тяжити, тяжка (7, с. 69).

Фразеологічні словники фіксують незначну кількість мовних одиниць, що номінують вагітність, а саме: $y$ поважному стані «вагітна» (9, с. 690); увійти в тяж (12, с. 910); ходити на вазі (12, с. 931); ходити важкою (12, с. 930); бути тяжі, тежі, тєгота (13, с. 253). Натомість високою частотністю відзначаються сталі звороти, сформовані внаслідок евфемізації, у яких певні позамовні, етносоціальні чинники спричиняють переосмислення явища материнства й утворення специфічних лінгвоодиниць. Такі вислови мають відчутний діапазон зашифрованості, як-от: в аптеці чергу займати (10, с. 39); не хватає грошей купити (10, с. 158); трудовий мозоль натерти (10, с. 336); носити за пазухою (10, с. 372); тудисюди - приїхали (10, с. 406); надута на життя (10, с. 206) жінка 3 грошима (10, с. 206); багата жінка (10, с. 206) тощо.

Культурно детермінованими образами 3 виразною оцінкою фізіологічного стану $є$ фраземи, які вказують: 1) на позначення процесу народження, підготовки до пологів: 3 дня на день розродиться (10, с. 168); пелюшки готувати - «чекати на дитину» $(10$, c. 378$) ; 2)$ на параметри жіночого тіла, зовнішній вигляд вагітної (переважно повнота живота, вага): як діжка (зі словом товста) (10, с. 176); живіт вище носа (10, с. 203); з животом (10, с. 203); боката жінка (10, с. 206); брюхата жінка (10, с. 206); не пуста жінка $(10$, с. 206$)$; ходити важкою $(10$, с. 80$)$. Вислови вишенька пузата $(10$, с. 94$)$; бути з ікрою $(10$, с. 227$)$ постали на основі метафоричного перенесення, зовнішньої подібності (округлості форми у вишні й живота вагітної жінки) й уподібнення до тваринного світу (відкладання ікри рибами). Внутрішня форма таких зворотів відчутно прозора, спирається на семантику компонентів сталих виразів. Зооморфний код фразеологізмів репрезентовано орнітонімами в таких

○ Г. Г. Демиденко, 2016. $-46-$ 
ФО: аїста ждати (10, с. 36); примітити лелеку (10, с. 303); журавлика вловила (10, с. 208). Як зазначає В. Ужченко, міф про те, що дітей приносить лелека $\epsilon$ найпопулярнішою у фольклорі європейських народів [10, с. 194]. В українській культурі лелеку сприймають як Божу птицю, символ добра, адже в народі 3 цим птахом пов'язані добрі ознаки, він символізує щастя, добробут, затишок у домі. Щасливою вважається та родина, у якої на даху хати чи іншої будівлі оселялася лелека. Цікаво також, що журавель символізує сторожкість, відлюдність [3, с. 226]. У зв'язку з цим можна висловити припущення, що згадка про такого птаха є небезпідставною зважаючи на делікатний стан вагітної, iï занепокоєння, побоювання стосовно дитини, бажання відокремитися від людей, сторонніх очей, почасти усамітнися.

Сталі звороти при надї бути (6, с. 17), при надї $(13$, с. 97) пов'язаний 3 вагітністю i репрезентує реалізацію бажаного, потрібного, приємного; позитивний, обнадійливий. За народними традиціями, надію вважали за опору на нелегкій життєвій дорозі, тому i3 зародженням нового життя перед майбутньою матір'ю також відкривається інший шлях. У болгар побутує вислів жена на $\mathrm{nъm}$, що означає дослівно «жінка на шляху», тобто перед жінкою має відкритися нова світла дорога. У фразеографічній праці до виразу при надії бути $(12$, с. 523) є суттєве зауваження, яке полягає в уточненні періоду вагітності, а саме - на останньому місяці, перед пологами. На часовий діапазон також вказує й вислів на останніх днях, тобто «перед пологами, перед народженням дитини» (12, с. 251).

Власне процес настання вагітності, який на Бойківщині номінують зневажливо набиратися $(6$, с. 6$)$, має свою реалізацію у фраземах, уживаних на Сході України. Аналіз фактичного матеріалу засвідчує, що стійки звороти ілюструють поважний жіночий стан як результат впливу чогось на жіночий організм. Так, скажімо, у ФО йдеться про продукти, з'їдені майбутньої породіллею, а саме: груш об ’̈стися (10, с. 159); арбузів наїстися (наковтатися) (10, с. 40); переїсти капусти (10, с. 234). 3-поміж дібраних лінгвоодиниць викликають інтерес ті, що кваліфікують вагітність як результат інтимних стосунків 3 чоловіком. Фразеологізми цього образносемантичного плану сформувалися за участю власних назв, наприклад: ждати Андрюшку від Гаврюшки (10, с. 39) або з указівкою 
на вагітність невідомого від кого: від Ваньки Ветрова (10, с. 83); надуло від Ваньки Вєтрова (10, с. 83); од Вєтра Вєтрового (10, с. 90).

Вислови жива риба наснилась (10, с. 421); упіймати рибу $(10$, c. 422$)$ пов'язані із сакральним змістом лексеми риба. У народній традиції слов'ян вважається, що бачити вві сні живу рибу до здоров'я, а неживу (що заснула) - до хвороби, або, якщо приснилася риба, то буде прибуток, а сон, що ти їв рибу - до збитку [8, с. 444]. За спостереженнями В. Проппа, у казках часто йдеться про народження від з'їденої риби. Цей мотив пов'язаний з архаїчним обрядом з'їдання тотемного предка 3 метою повернення його до життя [5, с. 227]. Для народної культури $є$ характерним осмислення риби як символу вагітності, плодючості, багатства, «сексуальної сили, мудрості, але й жадібності, байдужості, дурості» [2, с. 418]. Однак тлумачення снів 3 баченням риби неоднозначне: «Якщо сняться риби, буде слабкість», «Коли сняться риби, буде сварка», «Коли сняться риби, що плавають у річці, то це марні надії» [3, с. 498].

Темпоральні характеристики стали підгрунтям для утворення фразем, що демонструють неможливість завагітніти: третій год на дев'ятому місяиі (10, с. 132); третій год на п'ятім місяиі (10, с. 132); третій год на третім місяці (10, с. 132).

Пологи як процес можна схарактеризувати з позиції того, хто народжує й того, хто народжується. Сакральність дій, виконаних породіллею, репрезентовано стійкими виразами, як-от: ловити дітей $(10$, с. 178); вловити дитину (10, с. 172); приводити на світ [Божий] $(9$, c. 558). Евфемістичні фраземи виникають як замінники для прямого називання «вагітності й народження поза шлюбом»: принести в пелені (у приполі) (9, с. 564); принести в подолі (10, с. 395); нагуляти дитину (10, с. 172); залетіти в гречку (10, с. 156). Очевидно, уживання наведених висловів має на меті запобігти комунікативному конфлікту, оскільки така вагітність викликає осуд, обурення, соціальну ізоляцію.

3 позиції дитини процес появи на світ, який на Гуцульщині має назву чинитися - «народжуватися» (1, с. 214), реалізовано в таких ФО: полку прибуло - «з'явився на світ, народився хто-небудь» (9, с. 558); прийти на (у) світ (життя) (9, с. 561).

За нашими спостереженнями, сталих зворотів, пов'язаних iз називанням процесу вигодовування дитини, піклування про неї, не ○ Г. Г. Демиденко, 2016. 
зафіксовано ні академічним словником, ні словником говірок. Дібраний фактичний матеріал, що ілюструє явище материнства, пов'язаний також із взаємодією матері й дитини в післяпологовий період називають: 1) процес грудного вигодовування, власне годування: заплікувати - «перший раз годувати грудьми дитину» (13, с. 123); плекати - «годувати груддю» (1, с. 151]; напихати (згрубіле) - «насильно годувати дитину» (6, с. 27); 2) процес догляду за дитиною, піклування: затиліпати, затилипати (згрубіле) «3. Заколисати» (5, с. 37); гутати - «гойдати» (4, с. 98); 4) процес педагогічних упливів, дій: вікішкати - «виростити, виходити» (4, с. 65); кохати - «виховувати, ростити» (1, с. 104).

В українській культурній традиції відображено архетипне сприйняття матері, асоційоване 3 такими якостями, як турбота i співчуття, захист, піклуванням і підтримкою. Унаслідок аналізу мовного матеріалу були окреслені біологічна й соціальна сутність материнства, зокрема розглянуто сталі звороти на позначення процесу вагітності, народження дитини, ii годування, піклування. Лінгвокультурні особливості явища «материнства» реалізуються на тлі культурних кодів (соматичний, зооморфний, харчовий тощо), у механізмах утворення фразем евфемістичного характеру.

Продовження розпочатого дослідження вбачаємо в розгляді особливостей лексико-фразеологічного втілення явища дитинства, розгляду особистості дитини крізь призму мови.

\section{Література}

1. Великий тлумачний словник сучасної української мови [уклад. і голов. ред. В. Т. Бусел]. - К.-Ірпінь : ВТФ Перун, 2009. - 1736 с.

2. Войтович В. Українська міфологія / Валерій Войтович. - [вид. 2-ге, стереотип.]. - К. : Либідь, 2005. - 664 с.

3. Жайворонок В. Знаки української етнокультури : [словник-довідник] / В. Жайворонок. - К. : Довіра, 2006. -703 с.

4. Левченко О. П. Фразеологічна репрезентація світу / О. П. Левченко // Мовні і концептуальні картини світу : [зб. наук. праць]. - Київ : КНУ, 2002. - №7. - С. 307315.

5. Пропп В. Я. Фольклор и действительность : [избр. статьи] / В. Я. Пропп. - М. : Наука, 1976. - 324 с.

6. Рамих В. А. Материнство и культура : философско-культурологический анализ / В. А. Рамих. - Ростов-на-Дону : Изд. центр ДГТУ, 1997. - 143 с.

7. Рыжкина А. А. Концепт «мама» как один из родственный составляемых концепта «семья» в украинском, английском и китайском языках / А. А. Рыжкина // 
Вісник ЛНУ ім. Тараса Шевченка. - Луганськ, 2013. - № 12 (271). - Ч. 1. - С. 95-100.

8. Савченко Л. В. Феномен етнокодів духовної культури у фразеології української мови : етимологічний та етнолінгвістичний аспекти : [монографія] / Л. В. Савченко. - Сімферополь : Доля, 2013. - 600 с.

9. Селіванова О.О. Нариси з української фразеології (психокогнітивний та етнокультурний аспекти) : [монографія] / О. О. Селіванова. - К. ; Черкаси : Брама, 2004. - $276 \mathrm{c}$.

10. Ужченко В. Д. Фразеологія сучасної української мови : [навч. посіб.] / В. Ужченко, Д. Ужченко. - К. : Знання, 2007. - 494 с.

11. Фромм Э. Здоровое общество // Хорни К., Фромм Э. Психоанализ и культура. - М. : Юрист, 1995. - 596 с.

12. Чернова А. Підконцепт МАТИ БОЖА в українській мовній картині світу / А. Чернова // Вісник Запорізького національного університету. Філологічні науки : [зб. наук. праць]. - Запоріжжя : Запорізький національний університет, 2012. - № 1. C. $480-486$.

\section{Список використаних джерел}

1. Гуцульські говірки. Короткий словник / Відп. ред. Я. Закревська. - Львів : Вид-во Львівської обл. книж. друк., 1997. - 232 с.

2. Деркач П. М. Короткий словник синонімів української мови. - К. : Радянська школа, $1960-200$ c.

3. Лисенко П. С. Словник поліських говірок / П. С. Лисенко. - К. : Наукова думка, 1974. - 261 с.

4. Матеріали до словника Буковинських говірок / Відп. ред. - В. А. Прокопенко. - Чернівці, ЧДУ, 1971. - Вип. 1. - 100 с.

5. Матеріали до словника Буковинських говірок / Відп. ред. - В. А. Прокопенко. - Чернівці, ЧДУ, 1972. - Вип. 3. - 87 с.

6. Матеріали до словника Буковинських говірок / Відп. ред. - В. А. Прокопенко. - Чернівці, ЧДУ, 1979. - Вип. 6. - 108 с.

7. Москаленко А. А. Словник діалектизмів українських говірок Одеської області / А. А. Москаленко. - Одеса : Вид-во ОДПУ ім. К. Д. Ушинського, 1958. - 76 с.

8. Онишкович М. Й. Словник бойківських говірок : у 2 ч. - Ч. 2. - А-Н / М. Й. Онишкович. - К. : Наукова думка, 1984. - 497 с.

9. Словник фразеологізмів української мови [уклад. В. М. Білоноженко та ін.]. К. : Наукова думка, 2003. - 1104 с.

10. Ужченко В. Д. Фразеологічний словник східнослобожанських і степових говірок Донбасу / В. Д. Ужченко, Д. В. Ужченко. - [6-е вид., перероб. й доп.]. Луганськ : Вид-во ДЗ «ЛНУ ім. Тараса Шевченка», 2013. - 552 с.

11. Фразеологічний словник лемківських говірок Східної Словаччини Н. Вархол, А. Івченко. - Пряшів : Словацьке педагогічне видавництво, 1990. - 160 с.

12. Фразеологічний словник української мови / Уклад. В. М. Білоноженко ; за ред. Л. С Паламарчука. - Київ : Наукова думка, 1993. - 984 с.

13. Шило Г. Наддністрянський регіональний словник / Г. Шило. - Львів-НьюЙорк : Інститут українознавства ім. І. Крипякевича НАН України, 2008. - 288 с.

Стаття надійшла до редакиії 15.10.2015 p.

() Г. Г. Демиденко, 2016. 